\title{
Midwinter Meeting of the Association of Southeastern Research Libraries
}

The Association of Southeastern Research Libraries met in the Otto G. Richter library at the University of Miami on Monday evening, January 8, at 8 p.m. David Kaser (JUL), chairman, presided at the meeting. The minutes of the January 23, 1967, meeting in New Orleans were approved. The treasurer's report as attached was accepted as presented. It revealed that there is $\$ 5,000$ available for some "useful purpose" of the Association.

Porter Kellam (Georgia) reported on The Guide to Distinguished Collections. Through the effort of Guy Lyle (Emory), the Mary Reynolds Babcock Foundation grant was made available for the assembling of this guide, under the direction of Thomas English of Emory University. There are approximately fifty collections described in the guide, with approximately one-half to three pages devoted to each collection. There is a bibliography and an index. It is estimated that the manuscript will be completed by the end of January and turned over to the University of Georgia Press which has agreed to publish it. A motion was made by Jerrold Orne (North Carolina) that Guy Lyle and Porter Kellam discuss the matter of the contract for the Guide to the Distinguished Collections with the University of Georgia Press and represent the Association of Southeastern Research Libraries in whatever way they believe to be best. This was seconded and passed.

Porter Kellam (Georgia) read the report written by Ray Hummel (Virginia State Library) for the committee inventory of Southern Broadsides. The recommendation of the committee was that each state list be edited by a state editor and that each state list be issued separately. These recommendations reflect the problems which the committee faced in trying to edit one list combining the reports from all of the states. There was an expression from the entire group that a single list would be more useful than separate state lists. Dr. William Stanley Hoole (Alabama) made a motion that the committee continue its work for another year and hold to the original idea of one single publication and that funds for an editor be made available, the amount to be recommended to the chairman by the committee. This was seconded and passed.

Jerrold Orne (North Carolina) reported for the Committee on Newspaper Desiderata. The grant proposal presented by ASERL was denied, but Mr. Orne has agreed to try again. It was felt that, if we could not get money for a central file of newspapers, it might be possible to get commitments from each library to complete a file of one newspaper until the entire list of newspapers is held in the Southeast. It was recommended that action on the Newspaper Project be held in abeyance until the summer. If the second attempt for a grant proposal failed, Mr. Orne was instructed to bring a new proposal to ASERL.

Mack Abel (Tennessee) reported on the Foreign Newspaper Committee Project. Each member had received a summary of the questionnaires through the mails before the meeting. Mr. Abel has written to holders of negatives of the papers as to the cost and what is available. It was suggested that there be coordination with the ARL project and with the Southern Historical Association project.

Theodore N. McMullen (LSU) reported that the project to list the holdings of state newspapers held in each state had not been activated in many states. The chairman of ASERL will appoint a state chairman for each state to report the state newspaper holdings to ASERL.

Mr. McMullen reported that LSU annual statistics are the oldest continuous statistics, having been published since 1927. Dr. Kaser read a letter to Mr. McMullen from Keyes Metcalf. Mr. Porter Kellam will send a new list of statistics with all the members included shortly after the meeting to replace an earlier incomplete list.

The program consisted of a discussion led by William Stanley Hoole (Alabama) concerning electronic intercommunication techniques and facilities in libraries. He reported that Videx, LDX, and Magnavox were the only three machines available for transmitting and that none could take an open book. An experiment at the University of Nevada showed that it cost one dollar per page to Xerox and transmit the page through these machines. Questions were raised as to what percent of the interlibrary loans were so urgent as to need facsimile transmission, particularly in the light of the cost of the machine.

A discussion of TWX revealed that many more libraries are using TWX than were reported to Dr. Hoole in his survey of last year. Most states aided by federal money are planning statewide library information networks using TWX and wide area telephone service. Dr. Kaser urged everyone to use TWX and proposed a meeting of ASERL reference librarians or interlibrary loan librarians for a 
one-day meeting on interlibrary loans and the use of teletype. It was brought out in the discussion that Sharon Schatz from the Library of Congress has made a report on all facsimile transmission systems now being used. This report would be available to those who wrote Mr.
Paul Reimers, Information Systems Office, Library of Congress.

At the end of this discussion, the meeting was adjourned and all members boarded the bus for the ride back to Bal Harbour.-(Mrs.) Margaret Knox Goggin, Secretary, Pro Tem.

\section{Southwest Academic Library Consortium}

The Spring of 1967 gave birth to another cooperative venture among institutions of higher education in the Southwest. Some twenty academic libraries in New Mexico, Oklahoma and Texas entered into a Consortium. The following statements were accepted at the first two meetings, March 28, 1967 in Albuquerque and October 10, 1967 in Portales, New Mexico.

1. Each institution will prepare a list of serial holdings, giving title and volumes held, and will send this list to all libraries in the combination.

2. A program of mutually exclusive serial purchase will be established, participation to be voluntary.

3. The institutions will explore the possibilities of specializing in the acquisition of serials by subject fields.

4. Upon the request of the librarian in any institution in the combination, a library will Xerox the contents pages of designated serials and will mail to the requesting library. A fee of ten cents will be charged for each page. Faculty members receiving contents pages may check articles they want their library to request via interlibrary loan.

5. A simple tally record of interlibrary loan transactions will be maintained by each institution. An annual exchange of records and billing, if so desired, at ten cents per page was agreed upon.

The annual year will be the Gregorian calendar year. Teletype messages will also be accepted in addition to regular interlibrary loan forms and checked contents page copies as request forms.

6. Several institutions already have TWX installations and others are anticipating installations. ALL institutions in the Consortium were asked to explore the possibility of teletype. If library use alone could not justify the expense a combined effort of the entire institution was urged.

Federal Grants under Type $C$ of the Higher

Education Act based on the Consortium were received by five libraries for a total of $\$ 152$,200.00 .

For the present, formal membership in the Consortium will be limited to academic insti- tutions of higher education. The Consortium will have two meetings each year, one in the Fall and one in the Spring. The place will change from one institution to another with the specific location of the next meeting to be decided at a regular meeting of the Consortium. The chairman for each meeting will be the head librarian of the institution following alphabetically on a continuous rotating basis beginning with Panhandle State College.

The third meeting of the Southwest Academic Library Consortium was scheduled at New Mexico State University in Las Cruces, New Mexico, March 15. Don Richardson, librarian at Panhandle State College, will act as chairman for the Spring meeting.

\section{LIBRARY COLLEGE JOURNAL}

The Library College Journal, a Magazine of Educational Innovation, is the latest in the growing list of professional journals in librarianship. Its orientation, however, makes it of special interest to readers of CRL. Volume 1 , Number 1, dated Winter 1968, offers eighty neatly packaged pages containing pieces by Louis Shores on modern media, methods, and librarians; E. J. Josey on a predominantly Negro library-college; Clarence J. Leuba on an ideal college; and University of Michigan professor of higher education Robert Blackburn on library-campus conflicts. As a welcome to the new journal, $C R L$ will reprint this last mentioned article in its May issue.

The Library College Journal, which will appear quarterly, presents several continuing departments, including reviews of innovation and experimentation, hardware and software, learning resources, community college developments, grants and proposals, architecture, and books. It is edited by Howard Clayton, and its editorial board comprises Dan W. Sillers, Louis Shores, Stafford North, Thomas Minder, Robert Jordan, and Sister Helen Sheehan. Its editorial office is at Box 173, Brockport, New York 14420. $L C J$ costs $\$ 8$ per year. 